\title{
EFFECT OF STAKEHOLDERS' INTIMACY ON QUALITY OF EDUCATIONAL SERVICES IN PRIVATE INSTITUTIONS IN NIGERIA
}

\author{
Stanley N. Ajalie ${ }^{1^{*}}$, Chinonye L. Moses ${ }^{2}$ and, Olaleke O. Ogunnaike ${ }^{3}$ \\ ${ }^{1} \mathrm{Mr}$, Covenant University, Nigeria, stanley.ajalie@stu.cu.edu.ng \\ ${ }^{2}$ Prof, Covenant University, Nigeria, chinonye.moses@covenantuniversity.edu.ng \\ ${ }^{3}$ Dr., Covenant University, Nigeria, olaleke.ogunnaike@covenantuniversity.edu.ng \\ ${ }^{*}$ Corresponding Author
}

\begin{abstract}
This paper examined the effect of stakeholders' intimacy on quality of educational services in private institutions in Nigeria. The study population consists of four private universities in Nigeria namely AUN, Covenant, Babcock and Baze Universities. The sample size was made up of 1200 students who patronize the services of these institutions selected based on random and convenient sampling techniques. In order to obtain relevant data for the survey, a well-structured questionnaire was used as an instrument. A total of 1200 questionnaires were distributed and a total of 1003 were retrieved and analysed. Data analysis was carried out with the aid of structural equation model (SEM) and statistical package for social sciences (SPSS) software. The findings showed that stakeholders' intimacy has a significant effect on quality of educational services. The study recommends that private educational institutions should ensure they offer quality services to their students in order to foster and promote loyalty and cordial relationships with their stakeholders.
\end{abstract}

Keywords: Stakeholders, Stakeholders Intimacy, Quality of Services

\section{INTRODUCTION}

In Nigeria, the quality of educational services has been on a steady decline for many years thereby having a negative effect on Nigerians both psychologically and economically. Also the effect of the COVID-19 pandemic has worsened the issue as most educational institutions both public and private were adversely affected thereby putting a hold on educational activities in the nation. Nigeria's population is estimated to be over 180 million people (Johndrow, 2020). To accommodate the growing number of students seeking a higher education degree, a population of this size necessitates tremendous growth in higher education. However, Nigerian higher education systems' ability to fulfil this responsibility is frequently frustrated by issues of finance, efficiency, equity, and, to a large extent, quality. Quality education, according to Salau et.al (2020), is the facilitator, bedrock, powerhouse, and driving force for a nation's strong socioeconomic, political, cultural, healthy, and industrial development, as public and private education institutions are key mechanisms increasingly recognised as wealth and human capital producing industries. According to the World Bank (2018), higher education is essential for all developing countries to flourish in a global economy 
where knowledge has become a critical competitive advantage. As a result, a country can achieve sustainable development by strengthening the capabilities of its people capital through higher-level training.

In recent years, the World Bank (2018) opined that if the trend of the increasingly poor educational services is not urgently reversed, the consequences will be the prevalence of crimes and criminality, ranging from mass murders, insurgency, militancy, armed robbery, kidnappings and drug abuse, among others. Therefore motivating or stimulating educational institutions to improve the quality of education received by its stakeholders is key for their emancipation and global economic sustainability. Some factors have been understood to have a positive effect on the quality of educational services which includes but are not limited to stakeholders' involvement, influence, interaction, consultation and intimacy. However, so little is known about the influence of stakeholders' intimacy and its effect on quality of services. Hence this study investigates the effect of stakeholder intimacy on the quality of educational services in private institutions in Nigeria.

\section{STAKEHOLDERS' INTIMACY}

Stakeholders' Intimacy measures the level of affection or sentiment that stakeholders have for the educational services an institution has to offer. It is an approach of stakeholder engagement that goes beyond merely interacting with stakeholders and informing them of the benefits of being associated with a particular institution but goes a step further to inquire from stakeholders their experiences through direct communication and symbolism with the institution (Arrizabalaga, Domenech, Trilla, \& Adam, 2018). This includes their opinions, perspectives or passion for such institutions as represented by their interests. Stakeholder's intimacy tends to shed light on stakeholders' feelings about an institution whether positive or negative. For instance, educational institutions may provide quality services in order to gain competitive advantage over rival institutions. Private institutions through the provision of various top notch equipment such as projectors, video conferencing tools and other materials that facilitate learning both online and offline tend to stand out from other institutions without the capacity to provide these learning aids (Brian, Josh \& Sarah, 2007). This in turn provides them enough opportunities to fix problems or grasp opportunities while it lasts. Educational institutions may envisage this as an opportunity to identify threats or challenges associated with stakeholders' interests and concerns and proffer solutions through various online avenues, including social networks, discussion forums, blogs, and video-sharing sites to outwit their rivals. By so doing, educational institutions are able to win the loyalty of their stakeholders, increase their patronage and attain a positive reputation in the eyes of their stakeholders.

\subsection{Quality of Educational Services}

Quality of educational services refers to the perception of the degree to which an institution's services meets stakeholder's expectations. The quality of educational services an institution provides whether private or public, has a significant influence on stakeholders' perception of the institution. This is because the quality of services provided by the institution to its students affects its profitability, customer base and reputation among others (Alabar, Ode \& Gbande, 2017). This is because perceived quality refers to stakeholders' assessment of the superiority or excellence of the services acquired from an institution (Ibidunni, Olokundun, Falola \& Ogunnaike, 2018). In terms of definition, service quality entails "the consumer's judgment about an entity's overall excellence or superiority". The ability of an educational institution to provide quality services to its stakeholders is crucial in establishing a positive reputation. Stakeholders appraise institutions based on the quality of their services as well as their ability to innovate. A high quality service tends to build the confidence of various stakeholders in the institution (Adeniji, Osibanjo \& Abiodun, 2015). To develop and foster good and positive relationships with stakeholders, educational institutions whether public or private must maintain quality, productivity, innovation, social responsibility, and good relations with its stakeholders.

\subsection{Objective of the Study}

The aim of this study is to determine the degree to which stakeholders' intimacy affect quality of educational services of private institutions in Nigeria. As such the following hypothesis was deduced;

$\mathrm{H}_{0 \text { : }}$ Stakeholders' intimacy has no significant effect on quality of educational services.

\section{MATERIALS AND METHODS}

The study focused on stakeholders' intimacy and quality of educational services in private institutions in Nigeria. The study was conducted amongst four private institutions in Nigeria namely AUN, Covenant, Babcock and Baze Universities. The selected institutions have been in existence for over ten years as such were deemed suitable for the study. The study made use of questionnaire to obtain data from respondents. 
Random and convenience sampling techniques which is a type of probability and non-probability sampling technique was adopted to reach the target population. A sample size of 1200 was used for the survey out of which 1003 were utilized. The statistical package for social sciences (SPSS) was used to examine the data.

\section{RESULTS}

Regression Analysis Showing Influence of Stakeholders' Intimacy on Quality of Educational Services.

\begin{tabular}{|l|c|c|c|c|c|c|}
\hline \multicolumn{1}{|c|}{ Model Summary } & & $\begin{array}{c}\text { Sum of } \\
\text { Squares }\end{array}$ & $\mathrm{df}$ & $\begin{array}{c}\text { Mean } \\
\text { Square }\end{array}$ & $\mathrm{F}$ & Sig. \\
\hline $\mathrm{R}=.546$ & Regression & 6602.405 & 1 & 6602.405 & 1624.369 & $.000^{\mathrm{b}}$ \\
\cline { 2 - 7 } $\begin{array}{l}\text { RSquare }=.298 \\
\text { Adj RSquare }=.294 \\
\text { Std. Error=2.01608 }\end{array}$ & Residual & 4068.662 & 1001 & 4.065 & & \\
\cline { 2 - 7 } & Total & 10671.067 & 1002 & & & \\
\hline
\end{tabular}

a. Dependent Variable: Quality of Educational Services

b. Predictors: (Constant), Stakeholders' Intimacy

The hypothesis was tested and the model summary values in the table revealed, $R=0.546$ which is the correlation indices of stakeholders' intimacy and quality of educational services. However, it can be concluded that the association between these two observed variables (stakeholders' intimacy and quality of educational services) is positive and high. The estimate of the strength of this relationship is revealed in the $\mathrm{R}^{2}=0.298$ termed the "coefficient of determination which indicates the proportion of variance in quality of educational services that is accounted for by stakeholders' intimacy. The $R^{2}$ of 0.298 is suggesting that about $29.8 \%$ of the variability of the amount of the quality of educational services can be "explained" by the relationship with the amount of stakeholders' intimacy. As much as $70.2 \%$ of the variability is yet unexplained indicating that there must be one or more other relevant factors that are related to quality of educational services. Also in this table is the coefficient table which shows how well the regression model significantly predicts the dependent variable. The $p<0.05$ indicates that, overall, the regression model statistically significantly predicts the outcome variable at $R=0.546, R^{2}=0.298, f_{(1,1002)}=1624.369, p<0.05$. This implies that stakeholders' intimacy has significant influence on quality of educational services. Therefore, the null hypothesis is rejected while the alternate hypothesis sustained.

\section{DISCUSSION AND IMPLICATIONS}

The hypothesis stated that stakeholders' intimacy has no significant influence on quality of educational services. However, findings revealed that there is a significant influence between stakeholders' intimacy and quality of educational services. A number of conclusions can be drawn from this finding. According to Shymko and Roulet (2017), the trend toward increased stakeholders' intimacy leads educational institutions to require new kinds of information in decision-making. They added that internal stakeholders have conflicting priorities making the interactions more complex than ever. Lauff, Knight, Kotys-Schwartz, and Rentschler (2020) indicated that to interact with the right stakeholders, educational institutions need relevant and impactful messaging as well as integrated operations to maximize pull-through efforts. Stakeholders can affect institutions in various ways, among which the determination of service quality constitutes one of their vital roles and heavily impacts on their decision making (Shymko and Roulet, 2017).

The implication of poor or substandard educational services is that stakeholders are less likely to patronize such institutions and would rather seek solace in rival institutions with high quality of educational services (Shamma, 2018). Hence, institutions with poor educational programmes risk losing both their current and potential customer base, customer loyalty, reputation and financial profits among other benefits.

\section{CONCLUSION}

This paper presents a conceptual model where stakeholder intimacy can be used as a tool to enhance quality of educational services. The model provides evidence that taking into account stakeholders level of affection or resentment for educational services can determine if stakeholders would continue to patronize an institution's services as such can positively or negatively affect an institution's productivity and performance levels, growth, development and future success. Therefore, it is imperative that educational institutions ensure they provide excellent and superior services if they are to retain customer loyalty, increase customer 
base and increased profits as well as promote good relations with their stakeholders.

\subsection{Limitation and Future Study}

Only three four private institutions were covered in this study. Hence, there is limitation in scope which will not permit generalization of the findings. Also future studies can also carry out a comparative analysis between public and private educational institutions in the country.

\section{ACKNOWLEDGEMENT}

The authors of this article acknowledge Covenant University for full sponsorship of this research.

\section{REFRENCE LIST}

Adeniji, A. A. \& Osibanjo, A. O. (2012). 'Human Resource Management: Theory \& Practice,' Lagos. Pumark Nigeria Limited.

Adeniji, A. A., Osibanjo, A. O., \& Abiodun, A. J. (2015). Corporate Image: A Strategy for Enhancing Customer Loyalty and Profitability. Journal of South African Business Research, 112 . Retrieved from http://eprints.covenantuniversity. edu.ng/8432/\#.XHfFkYgzaUk

Arrizabalaga, I., Domenech, M. S., Trilla, N. R., \& Adam, P. (2018). How can we measure stakeholders' engagement in research? A literature review (1). Retrieved on $16^{\text {th }}$ November, 2020 from Agency for Health Quality and Assessment of Catalonia website: https://aquas.gencat.cat

Brian, H. Josh, B., \& Sarah Glass (2007). Marketing's new key metric: Engagement for marketing leadership professionals. Forrester Research, Inc. pg. 1- 15.

Ibidunni, A.S., Olokundun, M.A, Falola, H.O. and Ogunnaike O.O, (2018). Descriptive analysis of organizational knowledge utilization in Nigeria's telecommunication industry: A focus on managerial implications. Academy of Strategic Management Journal, 17(2), PP.1-7.

Johndrow, A. (2020). Making Money in the Reputation Economy. The Reputation Institute, New York.

Kerr, R. (2016). Corporate reputation and corporate speech. The Handbook of Communication and Corporate Reputation, 459-470.

Robbins, J. (2017). Stakeholders and conflict management. Unfolding Stakeholder Thinking 2, 162-179.

Salau, O. P., Osibanjo, A., Adeniji, A., Falola, H., Igbinoba, E., Atolagbe, T., \& Ogueyungbo, O. (2020). Crystalising employment quality and behavioural outcomes of employees in the public service. Heliyon, 6(12), e05619.

Shafiq, Y., Shafiq I., Din, M. S., \& Cheema, K. U. (2019). Impact of Service Quality on Customer Satisfaction: A Study of Hotel Industry of Faisalabad, Pakistan. International Journal of Management \& Organizational Studies, 2(1), 49-53.

Shamma, H. M., (2018). Toward a comprehensive understanding of corporate reputation: concept, measurement and implications. International Journal of Business and Management; Vol. 7(16), 151169

Shymko, Y., \& Roulet, T. J. (2017). When does Medici hurt da Vinci? Mitigating the signalling effect of extraneous stakeholder relationships in the field of cultural production. Academy of Management Journal, 60(4), 1307-1338.

World Bank Group (2018). Faith based and religious organizations. Retrieved from The Power of Faith to Help End Extreme Poverty Accessed 03/08/2020. 